\title{
Effects of fluvalinate and amitraz on bee lice (Braula coeca Nitzsch) in honey bee (Apis mellifera $L$ ) colonies in Yugoslavia ${ }^{* * * *}$
}

\author{
JM Kulincevic 1, TE Rinderer 2, ${ }^{* \star *}$, VJ Mladjan 3 \\ 1 RO PKB Institute "Agroekonomik", Padinska Sekla 11000 Belgrade, Yugoslavia; \\ 2 USDA, ARS, Honey-Bee Breeding, Genetics and Physiology Laboratory, \\ 1157 Ben Hur Road, Baton Rouge, LA 70820, USA \\ 3 Veterinary Institute, Vojvode Toze 141000 Belgrade, Yugoslavia;
}

(Received 14 March 1990; accepted 27 September 1990)

\begin{abstract}
Summary - Braula coeca Nitzsch (Diptera, Braulidae) is killed in reasonably large numbers when honey bee colonies are exposed to fluvalinate in either aerosol or fumigant form. Similar treatments with amitraz do not appear to harm this dipteran commensal.
\end{abstract}

Braula coeca / acaricide / toxicity / commensal / Apis mellifera

\section{INTRODUCTION}

The bee louse, Braula coeca Nitzsch (Diptera, Braulidae), is a cosmopolitan inhabitant of honey bee, Apis mellifera L colonies (Nixon, 1982; Smith and Caron, 1985). The natural history of this highly adapted dipteran has been summarized by Eckert and Shaw (1977), Knutson (1978) and Morse (1987). Braula is generally regarded to be a commensal of honey bees. However, Bailey (1963) speculates that a high infestation of Braula on a single queen may impair her egg-laying efficiency. Benton (1896) reported collecting 75 flies from one queen. Also, the habit of immature forms of tunneling galleries through the cappings of honey may occasionally damage the value of comb honey products.

Although Braula lack economic importance, their presence in bee hives has greater importance because of Varroa jacobsoni. The 2 species might be confused by casual or inexperienced observers since adults of both Braula and Varroa have similar color and size. However, identifications can be made on other characteristics; the flies have 3 pairs of legs and are longer than they are wide while the mites have 4 pairs of legs and are wider than they are long.

\footnotetext{
* In cooperation with the Louisiana Agricultural Experiment Station.

** Mention of a proprietary compound or trademark make does not constitute an endorsement. This article reports research results and does not contain recommendations.

*** Correspondence and reprints
} 
The use of acaracides in conjunction with paper bottom board inserts to collect dead mites is a common technique used to detect Varroa (Dietz and Hermann, 1988). The reddish mites contrast with the light background of the paper and are easily counted. In many instances, counts represent experimental data or are used to make regulatory decisions.

This paper reports the response of Braula coeca to compounds used to control Varroa jacobsoni. The issue is important since the presence and frequency of Braula may confound identifications and counts of Varroa.

\section{MATERIALS AND METHODS}

A single apiary containing 60 colonies of honey bees, Apis mellifera carnica was studied in the winter of 1987. These colonies occupied hives with 2 Langstroth chambers, were of similar size (20 000-40 000 bees) and were broodless due to the winter season. The 60 colonies were randomly assigned to 4 groups, each of which received one of 4 experimental treatments. These treatments consisted of : 1) fumigation with 0.02 $\mathrm{g}$ of amitraz; 2) fumigation with $0.0025 \mathrm{~g}$ of fluvalinate; 3) aerosol treatment with $0.006 \mathrm{~g}$ of amitraz; and 4) aerosol treatment with $0.0012 \mathrm{~g}$ of fluvalinate.

Fumigation treatments were accomplished by burning smoldering strips of filter paper impregnated with $\mathrm{NaNO}_{3}$ and toxicant. The $\mathrm{NaNO}_{3}$ causes the ignited paper to smolder and produce smoke which carries the toxicant throughout the hive. Aerosols were prepared as water dilutions of toxicant which were applied by an air compression device VAT-1, made in Czechoslovakia. During aerosol applications the hives were closed for 7-10 min. The methods of delivering amitraz and fluvalinate in the doses chosen were based on reports of effective procedures using low doses of materials in the control of Varroa (Vesely et al, 1987; Kulincevic et al, 1990).

Treatments were applied to colonies on November 13,1987 . Paper bottom board inserts were used to collect the dead Braula through
$7 \mathrm{~d}$ following treatment. Numbers of dead Braula were determined from these inserts for each colony after the flies were distinguished from $\mathrm{Var}$ roa. All colonies were re-examined following a December 29th exposure to fluvalinate as a fumigant at $0.0025 \mathrm{~g}$ per colony. As before, paper inserts were used to collect dead Braula. The number of dead flies after $7 \mathrm{~d}$ was estimated for each colony.

Analysis of data, using square-root transformed data, began with one-way analyses of variance for treatment effects for each treatment period. Square root transformations were used to stabilize the variance among treatment groups. Duncan's multiple range tests on square root transformed data were used as post analysis of variance tests.

\section{RESULTS AND DISCUSSION}

After the first period of treatment only fluvalinate killed Braula and the fumigation technique or the higher dose of toxicant used in fumigation killed more $(P<0.05)$ (table I). Amitraz killed very few Braula regardless of the method of application or dosage. Both compounds killed large numbers of Varroa jacobsoni regardless of method of application or dosage (Kulincevic et al, 1991).

Braula mortality after the second period of treatment confirms the results of the first period. All colonies were fumigated with fluvalinate. Colonies that had previously been treated with amitraz contained Braula which died after the second treatment. Thus, Braula were present in the colonies but remained alive after amitraz treatment. The colonies which had originally been treated still contained some Braula which died following the second treatment.

No data were collected concerning the effects of treatment on larval forms of Braula. However, since Varroa is protected by wax cappings over the brood cells it infests, it is likely that larval Braula are similarly protected. 
Table $I$. The numbers $(X \pm S D)$ of Braula coeca dying within $7 \mathrm{~d}$ of treatment.

\begin{tabular}{ccccc}
\hline Period & $N$ & Treatment & $x \pm S D$ & \\
\hline \multirow{2}{*}{1} & 15 & FIFu & $11.0 \pm 6.6$ & $\mathrm{~A}$ \\
& 15 & FIAe & $4.1 \pm 1.9$ & $\mathrm{~B}$ \\
& 15 & AmFu & $0.2 \pm 0.6$ & $\mathrm{C}$ \\
& 15 & AmAe & $0.0 \pm 0.0$ & $\mathrm{C}$ \\
& & & & \\
& 15 & FIFu-FIFu & $2.9 \pm 4.0$ & $\mathrm{~A}$ \\
& 15 & FIAe-FIFu & $4.9 \pm 2.9$ & $\mathrm{~B}$ \\
& 15 & AmFu-FIFu & $13.3 \pm 10.0$ & $\mathrm{C}$ \\
& 15 & AmAe-FIFu & $11.9 \pm 8.4$ & $\mathrm{C}$ \\
\hline
\end{tabular}

Treatments for period 1 were: fumigation with $0.0025 \mathrm{~g}$ fluvalinate (FIFu), aerosol application of $0.0012 \mathrm{~g}$ fluvalinate (FIAe), fumigation with $0.02 \mathrm{~g}$ amitraz $(\mathrm{AmFu}$ ) and aerosol application of 0.006 amitraz (AmAe). In period 2, all the colonies used in period 1 were treated with $0.0023 \mathrm{~g}$ fluvalinate by fumigation. In each period, letters following means which are different are separate from the other means $(\alpha=0.05)$ according to Duncan's multiple range tests.

The observation that fluvalinate has the potential to kill Braula coeca is important information. Persons using the compound in association with experiments or in survey and detection programs must identify the arthropods they observe. Small numbers of Braula may interfere with the accuracy of quantitative data and even qualitative data in some circumstances.

Although Braula was found in every colony in this experiment, in no case were enough adults found to suggest that Braula is more than an interesting commensal of honey bee colonies. Its low frequency of occurrence suggests that naturally occurring mechanisms operate which keep populations of Braula coeca in check. Nonetheless, some beekeepers apparently consider $B$ coeca to be undesirable and wish to control it (Caron, 1985). Such concerns may become less common in areas where fluvalinate is used to control Varroa jacobsoni.

\section{CONCLUSION}

The natural constraints on Braula populations are not known. Although Braula is found in North America, it is only occasionally seen. Varroa jacobsoni was far more common in the colonies of this experiment, but the numbers found cannot be considered high. Because of such low numbers, there is every possibility that the intensive use of fluvalinate may threaten the survival of Braula coeca, at least in some localities throughout the world.

\section{ACKNOWLEDGMENTS}

We thank S M Buco for the statistical analyses.

This research was financed by the United States Department of Agriculture, Office International Cooperation and Development's Speical Foreign Currency Program and the YugoslavUnited States Joint Fund for Scientific and Technological Cooperation. 
Résumé - Action du fluvalinate et de l'amitraze sur le pou des abeilles (Braula coeca Nitzsch) dans des colonies d'abeilles (Apis mellifera $L$ ) en Yougoslavie. Le pou des abeilles, Braula coeca Nitzsch (Diptera, Braulidae) est un insecte hautement évolué, présent en faible quantité dans les colonies, partout où se trouve l'abeille domestique (Apis mellifera L). Un rucher de 60 colonies d'A $m$ carnica en Yougoslavie a été divisé en 4 groupes de 15 colonies. Chaque groupe a subi l'un des 4 traitements suivants : fumigation avec $0,02 \mathrm{~g}$ d'amitraze, fumigation avec $0,0025 \mathrm{~g}$ de fluvalinate, aérosol avec $0,006 \mathrm{~g}$ d'amitraze et aérosol avec $0,0012 \mathrm{~g}$ de fluvalinate. Un mois et demi plus tard elles ont toutes reçu une fumigation avec $0,0025 \mathrm{~g}$ de fluvalinate. Le fluvalinate, qu'il soit appliqué en fumigation ou en aérosol, a tué $B$ coeca, contrairement à l'amitraze qui ne l'a pas tué quelle que soit la modalité de traitement. En conséquence, des identifications précises des arthropodes moribonds devraient être faites lors des expériences et des dépistages concernant Varroa jacobsoni Oud utilisant du fluvalinate. La sensibilité de $B$ coeca au fluvalinate et ses faibles effectifs de population soulèvent la question du danger potentiel que représente l'usage du fluvalinate pour les populations locales de $B$ coeca.

\section{Braula coeca / acaricide / toxicité / com- mensal / Apis mellifera}

\section{Zusammenfassung - Die Wirkung von} Fluvalinat und Amitraz auf die Bienenlaus (Braula coeca) in Bienenvölkern in Jugoslawien. Die Bienenlaus Braula coeca ist ein kosmopolitischer Bewohner von Bienenvölkern (Apis mellifera). Diese hochspezialisierte Fliege (Diptere) wird überall in geringer Häufigkeit gefunden, wo die Westliche Honigbiene vorkommt. In einem Versuch in Jugoslawien mit 60 Völkern von Apis mellifera carnica warden vier verschiedene Behandlungsarten an Gruppen zu je 15 Völkern angewandt: Beräuchern mit Amitraz, Beräuchern mit Fluvalinat, Aerosol-Behandlung mit Amitraz und mit Fluvalinat. Danach wurden alle Völker mit Fluvalinat beräuchert.

Die Ergebnisse zeigten, daß Fluvalinat sowohl als Aerosol wie als Räuchermittel Braula coeca abtötete. Amitraz hingegen tötete in keiner Anwendungsform die Bienenlaus. Diese Ergebnisse weisen darauf hin, daß bei allen Versuchen, welche die Anwendung von Fluvalinat zur Bekämpfung von Varroa jacobsoni betreffen, die klare Bestimmung aller abgetöteter Arthropoden angegeben werden sollte. Die Empfindlichkeit von Braula coeca gegenüber Fluvalinat wirft darüber hinaus die Frage auf, ob nicht lokale Populationen, die an sich nur von geringer Größe sind, durch die Anwendung von Fluvalinat gefährdet werden könnten.

\section{Braula coeca / Akarizide / Giftigkeit / Apis mellifera}

\section{REFERENCES}

Bailey L (1963) Infectious Diseases of the Honey Bee. Land Books London Ltd, pp 176

Benton $F$ (1896) The Honey Bee. A Journal of Instruction in Apiculture. USDA Tech Bull, Washington, pp 118

Caron DM (1985) Braula coeca. In: The Illustrated Encyclopedia of Beekeeping (Morse RA, Hopper T, eds) EP Dutton Inc, NY, 53-54

Dietz A, Hermann HR (1988) Biology, Detection, and Control of Varroa jacobsoni: $A$ Parasitic Mite on Honey Bees. Lei-Act Publishers, GA, USA, pp 82

Eckert JE, Shaw FR (1977) Beekeeping. Macmillan Publishing Co, NY, pp 536 
Knutson L (1978) Insect: Diptera (flies) bee lice. In: Honey Bee Pests, Predators and Diseases (Morse RA, ed) Cornell Univ Press, NY, 129-137

Kulincevic JM, Rinderer TE, Mladjan VJ, Buco SM (1991) Control of Varroa jacobsoni in honey-bee colonies in Yugoslavia by fumigation with low doses of fluvalinate or amitraz Apidologie 22 (in press)

Morse RA (1987) The braulids. Am Bee J 127, 429-431
Nixon M (1982) Preliminary world maps of honey bee diseases and parasites. Bee World $63,23-42$

Smith IB Jr, Caron DM (1985) Distribution of the bee louse (Braula coeca) in Maryland and worldwide. Am Bee J 125, 294-296

Vesely V, Titera D, Mala J, Bacilek J, Gesner M (1987) Pyrethroids in the control of Varroa disease. Proc 31st Int Congr Apic Warsaw, 268-269 